\title{
Oocyte atresia in the Mangrove oyster, Crassostrea gasar (Dautzenberg 1891), (Bivalvia, Ostreidae) in tropical environment
}

\author{
Hamet Diaw DIADHIOU ${ }^{1 *}$, Ismaïla NDOUR ${ }^{1}$, Serigne Modou $\mathrm{SARR}^{2}$ and \\ Adama DJIMERA $^{3}$ \\ ${ }^{I}$ Senegalese Institute for Agricultural Research (ISRA), Dakar Thiaroye Oceanographic Research Center \\ (CRODT), Hann Research Center (PRH), BP 2241, Dakar, Senegal. \\ ${ }^{2}$ Higher Institute for Agricultural and Rural Training former ENCR of Bambey, University of Thiès, Senegal. \\ ${ }^{3}$ Senegalese American Bilingual School (S.A.B.S) / Dakar-Senegal. \\ *Corresponding author; E-mail: hamet_diadhiou@yahoo.fr, Tel: (+221) 338328262
}

\begin{abstract}
The mangrove oyster, Crassostrea gasar, is exploited in a natural state in the Casamance estuary in Senegal by rural women Diola. The decrease of its size on natural deposits and the remoteness of the harvesting areas, are at the origin of the Oyster culture project in Lower Casamance. It is in this context that the reproduction of the oyster, C. gasar in the Casamance estuary was studied between 1992 and 1994 to optimize its capture of its spats. Each month, a sample of about 30 adult oysters was collected at the same location in the Karabane region, $6 \mathrm{~km}$ from the mouth of Casamance. Of the thirty oysters monthly collected, 3-5 females were selected for study among larger individuals. A fragment of gonadal tissue was collected from each oyster and prepared for histological study: alcohol fixation, alcohol washing, dehydration, impregnation and paraffin embedding, cutting, staining, blade-slat assembly, and blade observation using a computer. A program has been installed to automatically calculate the occupation rate of the different oocytes observed. A large percentage of atretic oocytes are observed in follicles of the oyster gonad, within 04 months, before the main oyster reproduction period in the Karabane area. This situation would be caused when the reserves accumulated by the oysters during the gametogenesis of the oyster are insufficient in the quantity and quality of reserves accumulated by the oysters during the gametogenesis of the oyster.
\end{abstract}

(C) 2019 International Formulae Group. All rights reserved.

Keywords: mangrove oyster, reproduction, histology, atresia, Crassostrea gasar.

\section{INTRODUCTION}

The mangrove oyster Crassostrea gasar (Dautzenberg, 1891) is naturally present on the stilt roots of mangroves on the West African coast (Angell 1986, Lapègue et al., 2002), South America and French Guiana in southern Brazil (Lapègue et al., 2002; Lazoski et al., 2011; De Oliveira Ramos et al., 2014).
The natural habitat of these mangrove oyster populations is declining in many parts of the world under the combined effects of human activities and climate change (Kirby, 2004; Beck et al., 2011; De Oliveira Ramos et al., 2014). In the Casamance Estuary, located in southern Senegal (13 ${ }^{\circ} 04 \mathrm{~N}$ and $12^{\circ} 20$ $\mathrm{N})$, the large increase in salinity observed 
during the great drought that occurred between 1980 and 1990 resulted in the loss of vast mangrove areas (Andrieu and Mering, 2008; Bassène, 2016), a sharp reduction in oyster size and the remoteness of harvesting areas. To cope with this situation, the Research Institute for Development (IRD in French) and the Center for Study and International Cooperation (CECI in French), launched an oyster culture project in Casamance in 1988, to develop a modern selection of mangrove oysters in the region. In Casamance, the mangrove oyster is exploited by Diola women, at the end of the rainy season, between December and AprilMay. This traditional activity provides its actresses with monetary incomes that are invested in the needs of households and the schooling of children. Apart from marketing, the mangrove oyster is consumed in the households of the actresses of its collection.

The availability and abundance of mangrove oyster is highly dependent on the recruitment of young individuals from adult reproduction. In aquaculture, this optimization of recruitment requires good control of reproduction. Oocytes are one of the main factors limiting reproduction and recruitment in bivalves; their number and state of health depend to a large extent on the reproductive success of a given population (Cannuel and Beningera, 2005).

Oocyte atresia, which consists of oocyte resorption, is a common phenomenon observed after oviposition in most bivalve species (Suarez et al, 2005; Kim et al, 2014). The phenomenon is very little studied for bivalves in tropical area. Oocyte quality is an important factor for the survival and development of marine mollusc larvae (Honkoop, 2003; Ren et al., 2003; EnríquezDíaz, 2004; Hamida, 2004; Ortiz-Zarragoitia and Cajaraville, 2010). This phenomenon is associated with the lack of favorable conditions for oysters such as the food deficit, low temperatures and environmental contamination (Ortiz-Zarragoitia and Cajaraville, 2010).
The phenomenon is still very poorly known for bivalve molluscs living naturally in the tropics, especially in Africa. This discovery demonstrates the interest of the study of oocyte atresia in the mangrove oyster, Crassostrea gasar, of the Casamance estuary in southern Senegal.

\section{MATERIALS AND METHODS Material}

The mangrove oyster Crassostrea gasar (Dautzenberg, 1891), or mangrove oyster lives mainly in the estuary where it is perfectly adapted to the intertidal life. But it can also be found in the subtidal zone to more than $10 \mathrm{~m}$ of depth (Sandison and Hill, 1966; Marozova et al., 1991).

It is found in the Karabane sector, on the stilt roots of mangroves (Rhizophora racemosa), at the level of the tidal balancing zone, along the two banks of the Casamance River and its tributaries, all around the island of Karabane (Figure 1). Its exploitation (picking) is a feminine activity. Some 4,000 women used to do so in the years 1984 and produced around 10,000 tons annually (Cormier, 1992).

The study of the biology of the species began with the need to develop its aquaculture in Senegal around 1948, in Sierra Leone in 1974, in Guinea Conakry in 1985, in the Gambia around 1988 and the research for a quality guarantee of the products destined in hotels in Nigeria (1972-1974, 1976-1978).

In the wild, $C$. gasar is adult for a length between 13 and $18 \mathrm{~mm}$ against 10 to 15 $\mathrm{mm}$ in breeding (Marozova and al, 1991). Each female emits, according to her size, from 0.4 to 5 million oocytes (Valovaya, 1986) but it is not known how this fertility varies with age. The larvae, like most bivalve molluscs, is pelagic and spend about 3 weeks in open water before metamorphosing and settling on a solid support (Marozova and al, 1991).

The sexes are separated and the genital products are directly emitted into the aquatic environment where fertilization takes place (Blanc, 1962). The emission of gametes takes place all year long with, however, more 
intense emissions during the rainy season and during the transition from dry season-wet season. The emissions of the first period are however more important (Blanc, 1962; Sandison, 1962; Sandison and Hill, 1966; Hunter, 1969; Gilles, 1991; Marozovi and al., 1991; Diadhiou et Le Pennec, 2000).

\section{Methods}

The study on oocyte atresia, the subject of this article, focuses on the monthly sampling and analysis of about 30 oysters, between 1992 and 1994. On these oysters, 3 to 5 females whose tissues are prepared and fixed between blade and coverslip. On these samples, a gonad fragment is taken not far from the digestive gland and fixed in Bouin alcohol. These fragments are then washed in 2 alcohol baths at $95{ }^{\circ} \mathrm{C}$, then in 3 baths at 100 ${ }^{\circ} \mathrm{C}$ and dehydrated in 3 toluene baths before being impregnated in 3 liquid paraffin baths $\left(56-58{ }^{\circ} \mathrm{C}\right)$. After these operations, the tissue pieces are embedded in paraffin before being cut into 5 or $7.5 \mu \mathrm{m}$ ribbons, dewaxed, stained and mounted between blade and coverslip to be observed at the analyzer of a computer desk. An image analysis program was set up to evaluate the acini occupancy rate by the different types of oocytes present in the oyster's gonads and to test the differences observed from a statistical point of view (average comparison).

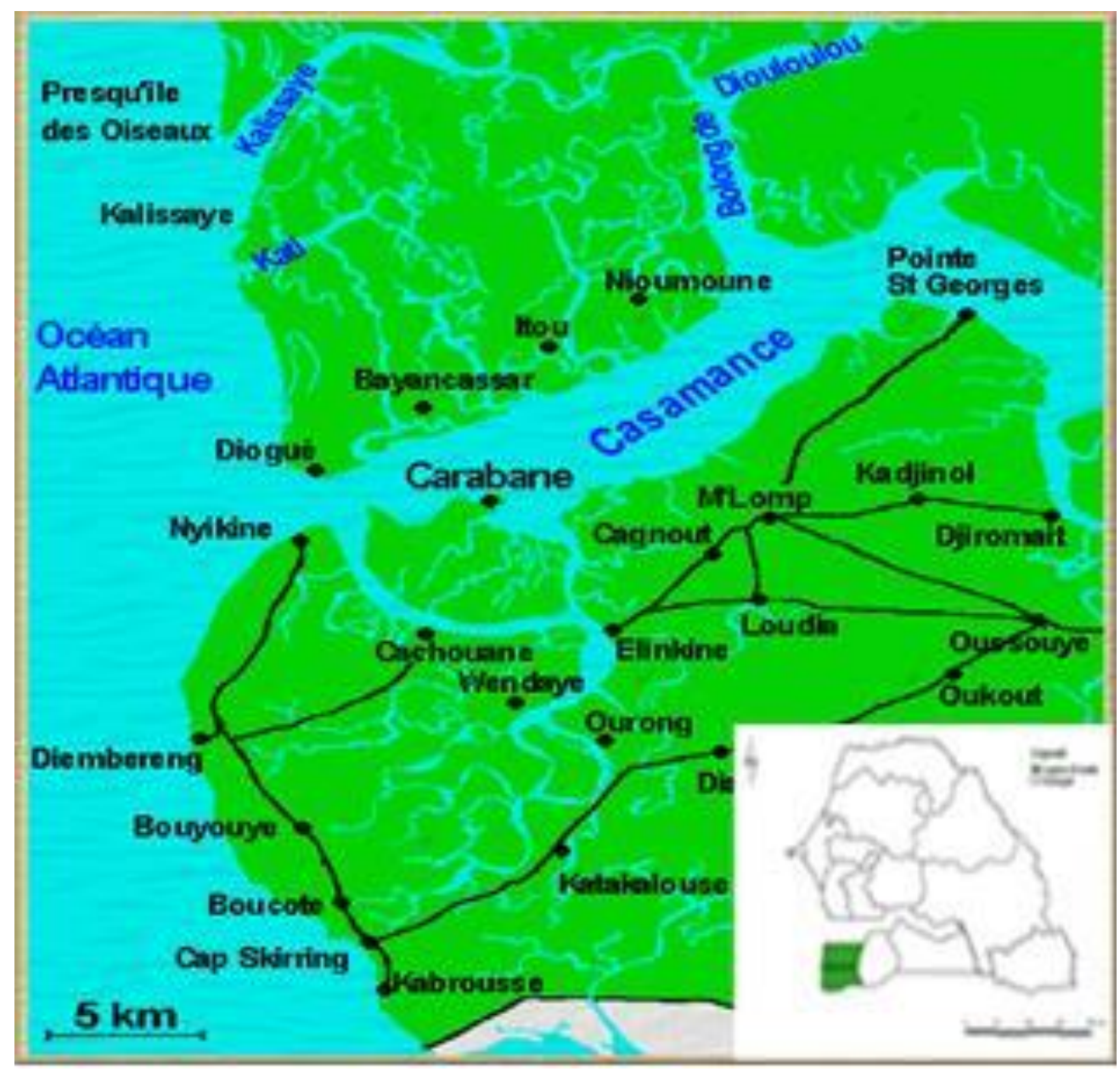

Figure 1: Location Map of Carabane Island (Source: Google). 


\section{RESULTS}

\section{Histological characteristics of oocytes found in mature oysters}

Atretic oocytes have very variable forms, of polyhedral type. Their cytoplasm is dark and homogeneous, their irregular vitelline envelope is often broken, releasing the contents of the oocyte into the environment. The nucleus and nucleolus are not observed in these cells (Photos 1-2).

On a semi-fine section, the observed content becomes less homogeneous, the periphery contains a large amount of dense inclusions and the center is clear (Photos 3). A large part of these inclusions is lipid in nature. Glycogen and proteins are present in these inclusions.

\section{Relationships between oocytes and their environment}

Atretic oocytes are present between oocytes in vitellogenesis and at the level of acini emptying or already emptied of their mature gametes (Photos 4-5). They are sometimes observed in the ducts evacuating gametes (Photos 6-7).

Table 1 shows the means and the standard deviations of the percentage of these oocytes in the acini near from other types (mature oocytes, adherents and that of the acini occupancy rate) during the months of August 1992 (pre-laying by the condition index study), September (laying), October (maturation period), November (laying period), March 1993 (expected period of sexual rest), April, May, July and August 1993 (atresia period is considered important), September (pre-laying) and during March 1994.

The Kruskal-Wallis test on the occupancy rates of different types of oocytes present in acini (mature, atretic, adherent oocytes) gave significant differences for atretic oocytes and adhered between July and August (Figure 2). The same phenomenon was observed between March and April, i.e. during sexual rest. A difference was observed in acini occupancy rates during the pre-laying and gamete emission periods in September. This was also the case for mature oocytes. On the other hand, there was no significant difference in the filling of acini between the pre-laying and laying periods (August and September), laying and maturation (October and November). The lowest value (slowed sexual activity) occurred in April 1993 and March 1994 (28.6 and 26\% occupancy). Atretic oocytes were largely dominant in acini over the study period (48 and 55\%). The occupancy percentage was high in November 1992 and July 1993 (over 50\%). In the first case, the gonad was predominantly occupied by atretic oocytes (nearly $56 \%$ of the surface) whereas in the second case, the acinus was mainly occupied by adherent and atretic oocytes, almost equal share (38\%). The lowest occupancy rate (slowed sexual activity) occurred in April 1993 and March 1994 (28.6\% and $26 \%$ occupancy). The lowest percentages of mature oocytes were observed in September 1992 and March 1994. The strongest were in September 1993. The percentage of mature oocytes varied widely between individuals in August, October and November 1992. At atresia oocytes level, the phenomenon was observed mainly in July and August 1993.

Oocyte atresia in the mangrove oyster, from the Karabane area, affects fully developed oocytes near from young germinal cells in vitellogenesis along the walls of the gonad acini. This phenomenon had spread over a relatively long period of more than 4 months in 1993 before a period of intense reproduction. 


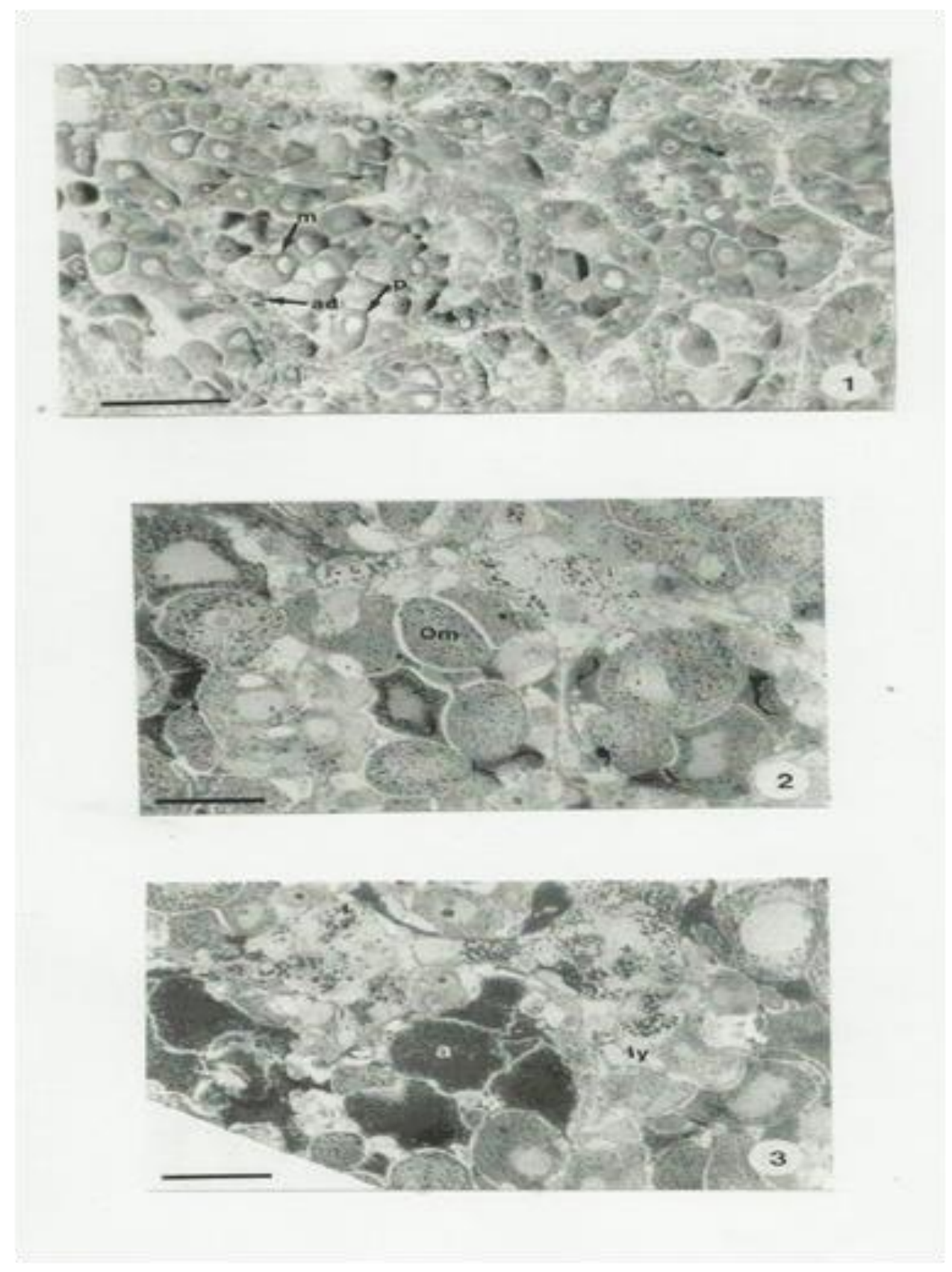

Photos 1, 2 and 3: Histological sections of gonads showing relative proportions: Photo 1: Adherent $(\mathrm{ad})$, pedunculate $(\mathrm{p})$ and mature $(\mathrm{m})$ oocytes. Note the variety of forms of mature oocytes. Scale: 100 micrometers;

Photo 2. Mature oocytes (Om). Scale: 30 micrometers;

Photo 3. Atretic oocytes (a) and dispersion of lysis products (ly). Scale: 30 micrometers. 

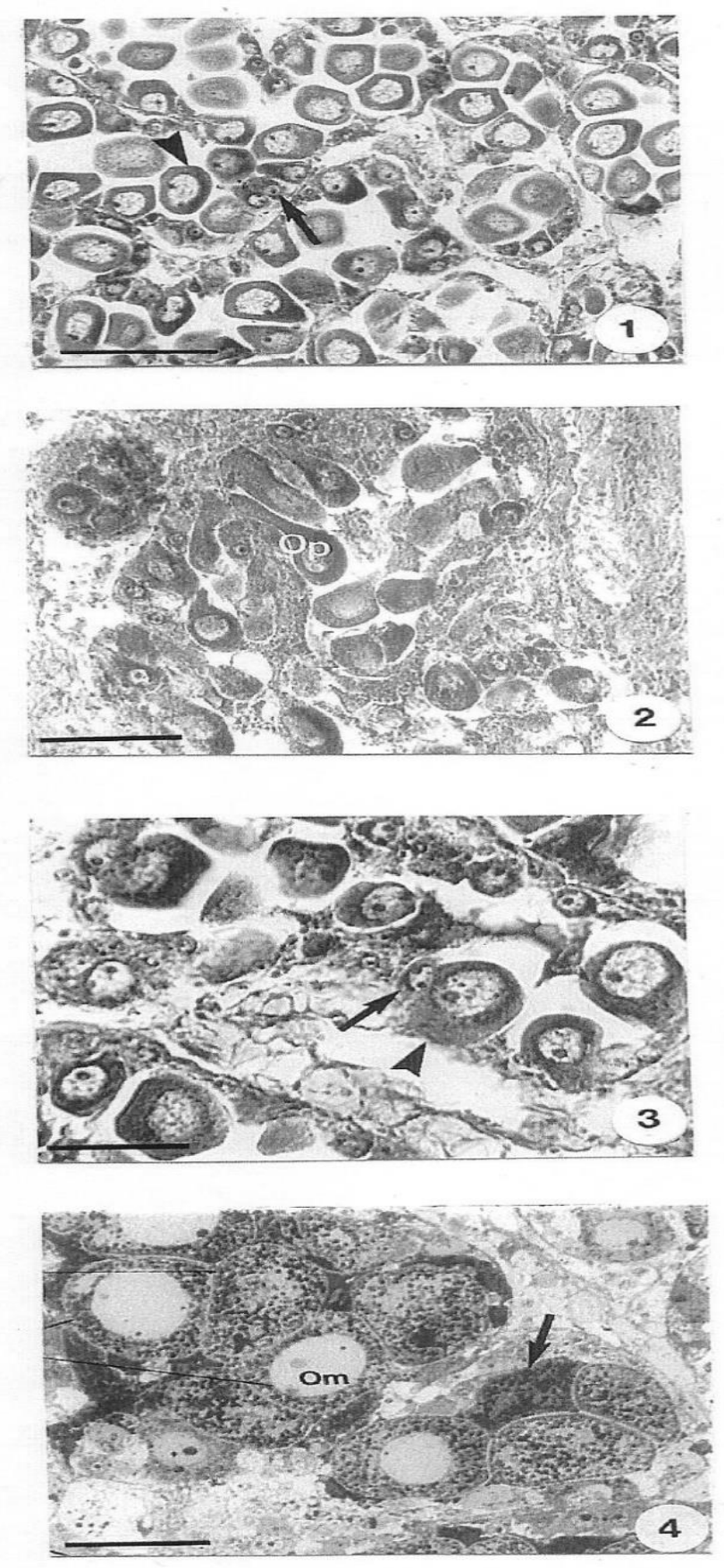

Photos 4, 5 and 6: The different forms of oocytes found in the acini of the mangrove oyster, Crassostrea gasar:

- Photo 4: ovogonia (->), note the clear appearance of the cytoplasm and the round shape of the nucleus. Mature oocyte (arrowhead). Scale: $100 \mu \mathrm{m}$.

- Photo 5: oocyte pedunculate (Op). Scale: $100 \mu \mathrm{m}$.

- Photo 6: previtellogenic oocyte ( $>$ ). Scale: $50 \mu \mathrm{m}$. 

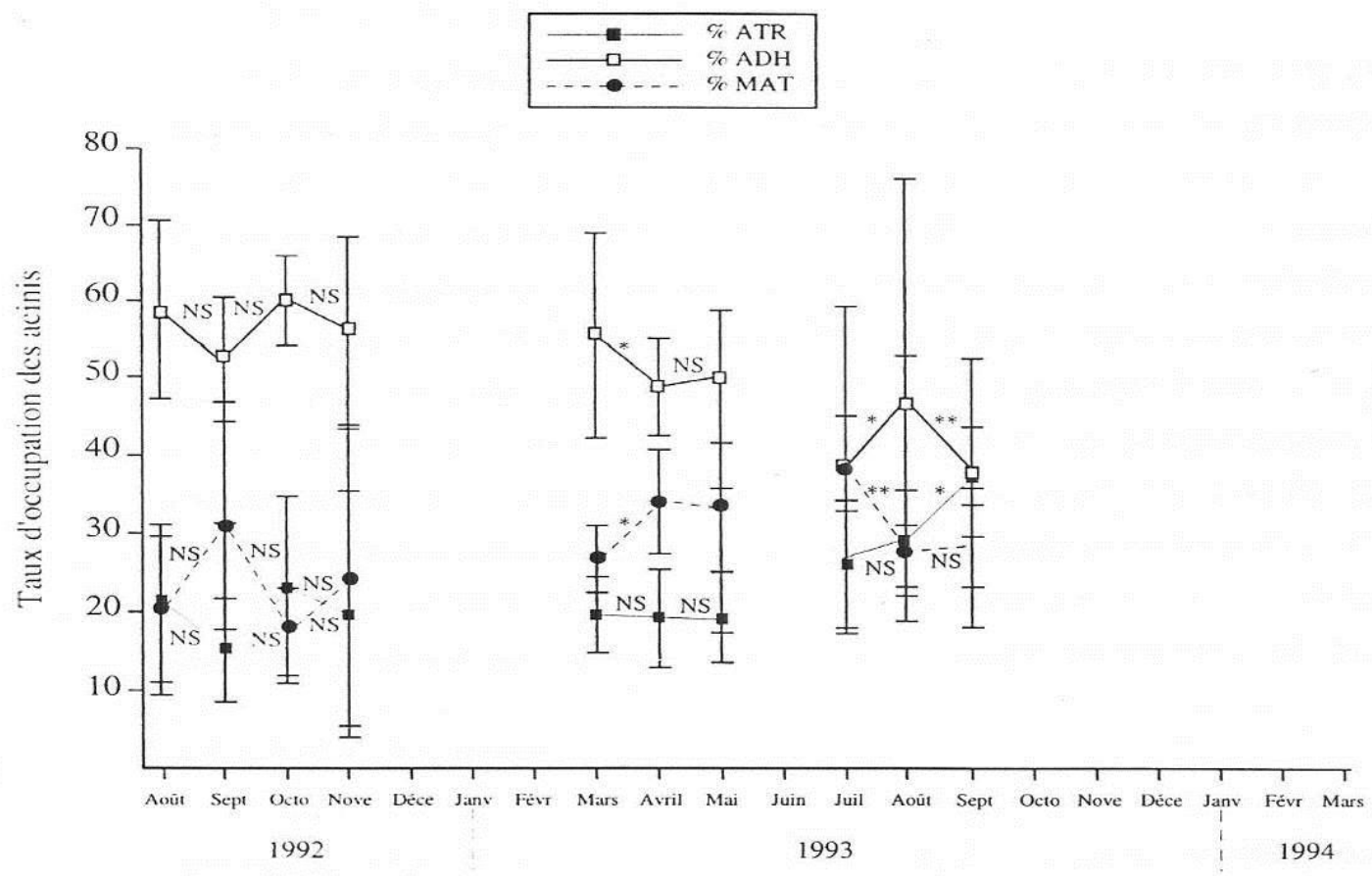

Figure 2: Monthly rate of occupancy of acini in casamance (Senegal) from 1992 to 1993.

$\% \mathrm{MAT}=$ Percentage of mature oocytes $\%$ ATR $=$ Percentage of atresic oocytes; \%ADH = Percentage of adherent oocytes ; NS = Non-signifiative test.

Table 1: Percentages of the number of mature, atretic, adherent oocytes and the acini occupancy rate during the characteristic months of the $C$. gasar reproductive cycle of the Carabane area in the Casamance estuary in southern Senegal.

\begin{tabular}{lllllllll}
\hline Date & \%MA & E\%MA & \%ATR & E\%ATR & \%ADH & E\%ADH & \%OCC & E\%OCC \\
& T & T & & & & & & \\
\hline August 92 & 21,36 & 10,11 & 59,00 & 11,33 & 19,65 & 10,27 & 38,27 & 11,33 \\
September 92 & 15,11 & 16,69 & 52,64 & 8,00 & 32,25 & 14,77 & 32,73 & 8,00 \\
October 92 & 22,73 & 11,93 & 60,02 & 5,91 & 17,25 & 5,70 & 44,38 & 5,91 \\
November 92 & 19,34 & 15,80 & 56,19 & 12,12 & 24,48 & 19,38 & 69,77 & 12,12 \\
March 93 & 18,85 & 4,86 & 55,08 & 13,38 & 26,07 & 4,40 & 22,53 & 13,38 \\
April 93 & 18,20 & 6,30 & 48,28 & 6,27 & 33,53 & 6,71 & 28,63 & 6,27 \\
May 93 & 18,08 & 5,86 & 49,52 & 8,70 & 32,40 & 15,98 & 42,01 & 8,70 \\
July 93 & 24,48 & 8,66 & 37,46 & 20,84 & 38,06 & 6,08 & 55,10 & 20,84 \\
August 93 & 28,28 & 6,31 & 46,27 & 28,82 & 25,45 & 4,66 & 49,48 & 28,82 \\
September 93 & 37,59 & 5,60 & 36,67 & 14,88 & 25,74 & 8,99 & 39,92 & 14,88 \\
March 94 & 14,40 & 9,71 & 54,75 & 20,59 & 30,86 & 6,41 & 26,03 & 20,59 \\
\hline
\end{tabular}

$\% \mathrm{MAT}=$ Percentage of mature oocytes $; \mathrm{E} \% \mathrm{MAT}=$ Standard deviation of percentage mature oocytes $; \% \mathrm{ATR}=\mathrm{Atresic}$ oocytes percentage $; \mathrm{E} \% \mathrm{ATR}=$ Standard deviation of atresic oocytes percentage $; \% \mathrm{ADH}=$ Adherent oocytes percentage $;$ $\mathrm{E} \% \mathrm{ADH}=$ Standard deviation of adherent oocytes percentage $; \% \mathrm{OCC}=$ Percentage of occupancy rate of acini $; \mathrm{E} \% \mathrm{OCC}=$ Standard deviation of percentage of acini occupancy. 


\section{DISCUSSION}

For Ramos and al (2014), this accumulation of energy reserves in mangrove oysters in Brazil is observed at temperatures above $22{ }^{\circ} \mathrm{C}$. This is the case noted in $C$. gasar in the Casamance estuary (Diadhiou and The Pennec, 2000).

Studies have shown the important role of temperature in the regulation of gametogenesis in C. gigas, in particular, the salinity, the quantity of available food and the high temperatures accelerate the germination of germ cells and allow the emission of gametes in this mollusc (Fabioux, 2004). Abundance of food is often considered to be a determining factor in the initiation of gametogenesis, then of its rhythmicity in bivalves (Thompson et al., 1996). The triggering of gametogenesis would depend on this abundance in temperate zones. The brutal variations of various factors, particular: sunshine, lunar illumination, phytoplankton blooms, would favor the emission of gametes. The quality of the oocytes depends mainly on the reserves accumulated by the parents before conditioning in $C$. virginica (ChávezVillalba et al., 2003).

Oocyte atresia observed over 4 months, before the main oyster reproduction period, towards the end of the rainy season in September, when the salinity of the estuary records is at its lowest values and the temperature of the water is around $30{ }^{\circ} \mathrm{C}$ (Diadhiou and Le Pennec, 2000). Devauchelle (2000) reports this action of temperature on the evolution of gametogenesis on bivalve molluscs in temperate regions. She had noted that when the temperature of the breeding water is too low, the gamete emission is not done for several weeks and even when the gonadal tissue contains mature gametes. The gametes are not expelled and are recycled in the digestive system. According to this author, the production of gametes in bivalves obeys thermal, photoperiodic, and saline preferenda. The appearance of abnormally high or low temperatures or salinities can cause the death of reproducer, block the emission of mature gametes, provoke their aging or induce gametic atresias. In the context of the Casamance estuary where salinity is one of the structuring factors of the environment (Cormier Salem et al., 2016), its involvement in the development of atretic oocytes is to be considered in the case of our study.

Gamete quality influences oyster larval growth (Gagne et al., 2003; Nice et al., 2003; Matozzo and Marin, 2005). Studies carried out in the field by these authors have revealed changes in vitelline reserves, sex ratio and gametogenesis delays in bivalve populations present in sites polluted with tributyltin, heavy metals and polycyclic aromatic hydrocarbons.

C. gigas parents require large amounts of food during hatchery packing, and some nutritional qualities are required for complete gametogenesis (Robert and Gerard, 1999).

In order to determine whether an abundant diet (current practice) or no diet during conditioning can influence oocyte quality, we tested the effects of two conditioning treatments, abundant feeding and starvation, on a whole of oocyte quality predictors of $C$. gigas clearly identified (lipid content, mature oocyte diameters, oocyte maturity and presence / absence of atresia).

Products derived from oocyte degeneration of lysis materials created by follicular cells (or helper cells) act as sources of metabolites that can be rapidly mobilized by the organism during the oocyte maturation phase (Chung et al., 2005, 2007; Son and Chung, 2009). In general, accessory cells called follicular cells appear in the invertebrate gonads and are often thought to play a role in oocyte nutrition during oogenesis (Fabioux, 2004; Kim et al., 2014). 
On the Atlantic coast in France, the oyster Crassostrea gigas uses carbohydrates and / or proteins as the main source for oocyte development (Chávez Villalba, 2001). This situation is explained according to this author would be due to a very significant adaptation to the specific environmental conditions of each cultivation site. The quantity and quality of reserves accumulated by oysters during gametogenesis has an influence on the quality of oocytes produced by the oyster. Larval rates ("D" larvae) are higher in oyster lots with more reserves.

Five reproduction periods were observed in the oyster C. gasar in the Karabane area during the period studied (Diadhiou and Le Pennec, 2000): November 1992, January, June, September and November 1993. Such a phenomenon is characteristic of species whose reproduction is spread over time (partial laying). In oysters with this characteristic, residual oocytes in the gonad undergo a regression phase in which cell contents are lysed (Beninger and Le Pennec, 1991; Steele and Mulcahy, 1999). The energy resulting from this resorption of gametes is reinvested in the metabolism.

\section{Conclusion}

The present study on the oocyte atresia of the mangrove oyster, Crassostrea gasar, carried out with the general objective of contributing to a better knowledge of its reproduction in order to promote its modern breeding, made it possible to characterize in part this phenomenon in this bivalve mollusc. The data presented in this study revealed the manifestation of oocyte atresia in C. gasar from the Casamance estuary. It would be important, however, specifically the biological aspects that accompany it as the fate of the nutrients contained in atretic oocytes and follicles present in the acini.

\section{ACKNOWLEDGEMENTS}

This work was carried out within the framework of the Oyster culture Project in Lower Casamance jointly funded by We thank the Research Institute for Development (IRD), the Canadian Agency for International Development (CIDA) and Professors Marcel Le Pennec and Yves Marie Paulet from the University of Western Brittany of Brest (France) for the support provided for the realization of this study.

\section{COMPETING INTERESTS}

The authors have declared that no competing interests exist.

\section{AUTHORS' CONTRIBUTIONS}

Conceptualization: HDD, IN. Data curation: HDD, IN, SMS. Formal analysis, methodology and software: HDD, IN and SMS. Project administration and resources, supervision: HDD. Validation, visualization, writing-original draft and writing-review \& editing: HDD, IN, SMS and AD.

\section{REFERENCES}

Andrieu J, Mering C. 2008, Cartographie par télédétection des changements de la couverture végétale sur la bande littorale ouest-africaine: exemple des Rivières du Sud du delta du Saloum au Rio Geba. Télédétection, Editions scientifiques GB, 8(2) : 93-118.

Bassène OA. 2016. L'évolution des mangroves de la Basse Casamance au sud du Sénégal au cours des 60 dernières années : surexploitation des ressources, pression urbaine et tentatives de mise en place d'une gestion durable. Géographie. Université de Lyon, 2016. Français. <NNT : 2016LYSES040>. 〈tel-01559306>

Beck MW, Brumbaugh RD, Airoldi L, Carranza A, Coen LD, Crawford C, Defeo O, Edgar GJ, Hancock B, Kay MC, 
Lenihan HS, Luckenbach MW, Toropova CL, Zhang G, Guo X. 2011. Oyster reefs at risk and recommendations for conservation, restoration, and management. Bioscience, 61:107-116.

Beninger PG, Le Pennec M. 1984. Seasonal variations in condition, reproductivc actrvity and gross biochemical composition of two species of adult clams reared in a common habitat: Tapes decassatus L., (Jeffieys) and Tapes philipinarum (Adams et Recve). $J$. Esph4arBiol. Ecol., 79 : 19-37.

Blanc A. 1962. Etude de l'huître des palétuvters (G @ @ea gasar Adanson). Rapp. L U.Péches, Sénégal, pp. 1-78.

Cannuel R, Beninger PG. 2005. Is oyster broodstock feeding always necessary? A study using oocyte quality predictors and validators in Crassostrea gigas. Aquat Living Res., 18: 35-43.

Chávez-Villalba J, Mingant C, Cochard J-C, Le Pennec M. 2001. Gamétogenèse chez 1.huître Crassostrea gigas de 1.Aber Benoît (Bretagne, France), à la limite nord de son aire de reproduction. Haliotis, 30: 1-12.

Chávez-Villalba J, Cochard J-C, Le Pennec M, Barret J, Enríquez-Díaz M, CáceresMartínez C. 2003, Effects of temperature and feeding regimes on gametogenesis and larval production in the oyster Crassostrea gigas. J. Shellfish Res., 22: 721-731.

Chung EY, Koh CH, Park GM. 2007. Oogenesis, oocyte degeneration and sexual maturation in female Cyclina sinensis (Gmelin, 1971) (Bivalvia Veneridae) in Korea. Integra Bio., 11: 191-198.

Chung EY, Park YJ, Lee JY, Ryu DK. 2005. Germ cell differentiation and sexual maturation of the hanging cultured female scallop Patinopecten yessoensis on the east coast of Korea. J Shellfish Res., 24: 913921.
Cormier-Salem MC, Panfili2m J. 2016. Mangrove reforestation: greening or grabbing coastal zones and deltas? Case studies in Senegal. African Journal of Aquatic Science, 41(1): 89-98.

Cormier-Salem MC. 1992. Contribution a l'étude géographique $\mathrm{C}^{\prime} \mathrm{X}$ évolution des.espaces aquatiques : la Casarnance. Thèse de doctorat de géographie. Universitté Picrrc et Marie Curie. Ed. ORSTOM ; 575p.

De Oliveira RC, Araújo De Miranda Gomes CH, Magenta MagalhãesAR, Dos Santos AI, De Melo CMR. 2014. Maturation of the Mangrove Oyster Crassostrea gasar at Different Temperatures in the Laboratory. Journal of Shellfish Research, 33(1):187194. https://doi.org/10.2983/035.033.0118.

Devauchelle N. 2000. Facteurs naturels de l'environnement et reproduction de poissons téléostéens et de mollusques bivalves en aquaculture, en zones tempérées. Le milieu aquatique : interactions des facteurs environnementaux et impacts sur les organismes vivants, Brest, septembre 1999.

Archimer.ifremer.fr/doc/00043/15470/128 49.pdf

Diadhiou HD, Le Pennec M. 2000. Reproduction of the oysters Crassostrea gasar (MOLLUSC, BIVALVE) in southern Casamance (Senegal). Mar. Life (Marseille), 10:19-25.

Enríquez-Díaz MR. 2004. Variabilité et bioénergétique de la reproduction chez l'huître creuse Crassostrea gigas. THÈSE DE DOCTORAT, (Spécialité : Océanologie Biologique). UNIVERSITÉ DE BRETAGNE OCCIDENTALE, 193p.

Fabioux C. 2004. Origine et développement des cellules germinales chez l'huître Crassostrea gigas: intérêt pour le contrôle de la reproduction en écloserie. 
Reproductive Biology.Université de Bretagne occidentale - Brest.French.<tel00009344>.

Gagné FCB, Pellerin J, Pelletier E, Douville M, Gauthier S, Clerc, Viglino LL. 2003. Altération sexuelle chez les myes (Mya arenaria) dans une zone intertidale du fleuve Saint-Laurent (Québec, Canada). Biochimie et Physiologie Comparatives Partie C: Toxicologie et Pharmacologie, 134(2) : 189-198. DOI : https://doi.org/10.1016/S15320456(02)00248-X

Gilles S. 1991. Observations sur le captage et la croissance de l'huître ouest-africaine Crassostrea gawr en Casamance. Rev. Hydr. Trop., 24(3) : 197-207.

Hamida L. 2004. Reproduction de la palourde Ruditapes decussatus, en milieu naturel (sud Tunisie) et en milieu contrôlé (écloserie expérimentale) : relation avec le système immunitaire. Immunologie. Université de Bretagne occidentale - Brest, 2004. Français. HAL Id: tel-00009544 https://tel.archives-ouvertes.fr/tel00009544 Submitted on 20 Jun 2005

Honkoop PJC. 2003. Physiological cost of reproduction in the Sydney rock oyster Sacrostea glomerata. How expensive is reproduction? Oecologia, 135: 176-183. Hunter JB. 1969. A survey of the the oyster population of the Freetown river Sierra Leone with notes on the ecology, cultivation and possible utilization of mangrove oysters. Trop. Sci., 2 : 278-285.

Kim SH, Ee-Yung C, Ki-Young L. 2014. Oocyte Degeneration Associated with Follicle Cells in Female Mactra chinensis (Bivalvia: Mactridae). Dev. Reprod., 18(4): 321-327. DOI: http://dx.doi.org/10.12717/DR.2014.18.4.3 21

Kirby RR, Bequgrqnd G. 2009. Trophic amplification of climate warming.
Proceedings of the Royal Society BBiological Sciences, 276, 4095-4103.

Lazoski C, Gusma o J, Boudry P, Sole'-Cava AM. 2011. Phylogeny and phylogeography of Atlantic oyster species: evolutionary history, limited genetic connectivity and isolation by distance. Mar. Ecol. (Berl.), 426: 197-212.

Lapègue S, Boutet I, Leitã A, Heurtebise S, Garcia P, Thiriot-Quie'vreux C, Boudry P. 2002. Trans-Atlantic distribution of mangrove oyster species revealed by $16 \mathrm{~S}$ mtDNA and karyological analyses. Biol. Bull., 202: 232-242.

Marazova AL, Leung Tack KD, Kholodov VI, Trousevich VVM, Camara S, Maskevski VK, Ibrahimov FX, Lamakin PD. 1991. L'Ostréiculture en milieux de mangroves (Etudes de cas en Guinée ct au Sénégal).COh4ARAF, 7. 148 p.

Matozzo V, Marin MG. 2005. Can 4nonylphenol induce vitellogenin-like proteins in the clam Tapes philippinarum? Environ. Res., 97: 43-49.

Nice HE, Morritt D, Crane M, Thorndyke M. 2003. Long-term and transgenerational effects of nonylphenol exposure at a key stage in the development of Crassostrea gigas. Possible endocrine disruption? Mar. Ecol. Prog. Ser., 256 : 293-300.

Ortiz-Zarragoitia M, Cajaraville MP. 2010. Intersex and oocyte atresia in a mussel population from the Biosphere's Reserve of Urdaibai (Bay of Biscay). Ecotoxicology and Environmental Safety, 73 : 693-701.

Ren JS, Marsden ID, Ross AH, Schiel DS. 2003. Seasonal variation in the reproductive activity and biochemical composition of the Pacific oyster (Crassostrea gigas) from the Marlborough Sounds, New Zeland. N. Z. J. Mar. Freshwater Res., 37: 171-182. 
Rene GA. 1999. Bivalve hatchery technology: The current situation for the Pacific oyster Crassostrea gigas and the scallop Pecten maximus in France. Aquatic Living Resources, $\quad \mathbf{1 2}(2)$ : 121-130. DOI: https://doi.org/10.1016/S09907440(99)80021-7.

Sandison EE. 1962. The populations of Balanus amphritrite var. Sttsburi on the Guinea coast. Proc. Zool. Soc. Land., 138: 517-542.

Sqndison EE, Hill MB. 1966. The distribution of the Balanus pullidus stutsbuyi Darwtn, Gypheu gasar [(Adanson) Dautzenberg], Mercierella enigmatica Fauve1 and Hydroides uncinata (Philippi)) in relation in Lagos harbour and adjacent creeks. Journal of Anima Ecology, 35: 235-250.

Son PW, Chung EY. 2009. Annual reproductive cycle and size at first sexual maturity of the sun and moon scallop Amusium japonicum japonicum (Gmelin, 1791): (Bivalvia Pectinidae) in the coastal waters of Jejudo, Korea. Malacologia, 51: 119-129.
Steele S, Mulcahy MF. 1999. Gametogenesis of the oyster Crassostrea gigas in southern Ireland. J. Mar. Biol. Ass. U.K., 79: 673686.

Suarez MP, Alvarez C, Molist P, San Juan F. 2005. Particular aspects of gonadal cycle and seasonal distribution of gametogenic stages of Mytilus galloprovincialis cultured in the estuary of Vigo. J. Shellfish Res., 24: 531-540.

Thompson RJ, Newell IE, Kennedy VS, Mann R. 1996. Reproductive processes and early development. In The Eastern Oyster Crassostrea virginica, Kennedy VS, Newell IE, Eble F (Eds). Maryland Sea. Grant Publ. ; 335-370.

Valovaya NA, Kaba MS. 1990. Particularités biologiques de la reproduction de l'huître de mangrove Crassostrea tulipa. CERESCOR, 10: 126-1 37.

Wourms JP. 1987. Oogenesis. In Reproduction of Marine Invertebrates (vol. IX). General aspects: seeking unity in diversity, Gieseet AC (ed.). Blackwell Scientifc Publications and Boxwood Press: California; 49-178. 